With these potential sources of error in mind, the following recommendations are made concerning venepuncture for potassium estimations: (1) venous stasis is permitted but forearm exercise should be avoided immediately before and during venepuncture; (2) if forearm exercise has to be used the tourniquet should be released after venepuncture and the arm rested for two to three minutes before the blood sample is taken; and (3) plasma is preferred to serum, particularly if the blood cells cannot be separated immediately.

We are grateful to Mr. K. McElroy and Mr. S. McVeigh for technical assistance, and to the department of biochemistry, Western Infirmary, Glasgow, for potassium estimations in the patient referred to in the discussion.

\section{REFERENCES}

Brown, J. J., Davies, D. L., Lever, A. F., Robertson, J. I. S., and Tree, M. (1964a) Biochemical fournal, 93,594

Brown, J. J., Davies, D. L., Lever, A. F., Peart, W. S. and Robertson, J. I. S. (1964b) British Medical fournal, 2, 1636.

Brown. J. J., Davies, D. L., Lever, A. F., Peart, W. S., and Robertson, J. I. S. (1965). Fourmal of Endocrinology, 33, 279.

Brown, J. J., et al. (1967). In Proceedings of the 3rd International Congress of Nephrology, edited by J. S. Handler, vol. 1, p.226. Basel, Karger.

Brown, J. J., et al. (1968). Lancet, 2, 55.

Brown, J. J., et al. (1969a). Fournal of Endocrinology, 43, IV.
Brown, J. J., et al. (1969b). Proceedings of the Royal Society of Medicine, 62, 1258

Conn, J., Knopf, R., and Nesbit, R. (1964). In Aldosterone, edited by E. E. Baulieu and P. Robel, p.327. Oxford, Blackwell.

Conn, J. W., Cohen, E. L., Rovner, D. R., and Nesbit, R. M. (1965). fournal of the American Medical Association, 193, 200

Conn, J. W., Rovner, D. R., Cohen, E. L., and Nesbit, R. M. (1966). fournal of the American Medical Association, 195, 21.

Conn, J. W. (1968). Harvey Lectures, 62, 257.

Farber, S. J., Pellegrino, E. D., Conan, N. J., and Earle, D. P. (1951). American fournal of the Medical Sciences, 221, 678.

Fawcett, J. K., and Wynn, V. (1956). British Medical fournal, 2, 582

Fenn, W. O. (1936). Physiological Reviews, 16, 450

Fenn, W. O. (1940). Physiological Reviews, 20, 377

Fraser, R., and James, V. H. T. (1968). Fournal of Endocrinology, 40, 59.

Kaminer, B., and Bernstein, R. E. (1952). South African fournal of Medical Sciences, 17, 35 .

Hultman, E., and Bergström. J. (1962). Scandinavian fournal of Clinical and Laboratory Investigation, 14, Suppl. No. 64, p. 87

Luetscher, J. A. (1958). Annals of Internal Medicine, 48, 1424.

Luetscher, J. A. (1962). In The Human Adrenal Cortex, edited by A. R. Currie, T. Symington, and J. K. Grant, p.479. Edinburgh, Livingstone.

Luetscher, J. A. (1964). Medicine, 43, 437.

Pfleiderer, T., Otto, P., and Hardegg, W. (1959). Klinische W., Biglieri, E. G., Slaton, P., and Galante, M. (1966). Annals of

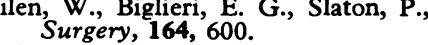

Skinner, S. L. (1961). Lancet, 1, 478.

Spark, R. F., and Melby, J. C. (1968). Annals of Internal Medicine, 69, 685

Whitfield, J. B. (1966). Fournal of Clinical Pathology, 19, 496.

\title{
Hygiene of Infant-feeding Utensils. Practices and Standards in the Home
}

\author{
J. A. D. ANDERSON,* M.A., M.D., D.P.H. ; A. GATHERER, $†$ M.D., D.P.H., D.I.H.
}

British Medical fournal, 1970, 2, 20-23

Cummary: Of 758 infants' feeding-bottles and teats $\checkmark$ collected aseptically by health visitors in four areas of Great Britain and examined in public health laboratories, less than two-thirds of the bottles and just over half of the teats produced results within an arbitrary "satisfactory" level. The mothers who said they used the hypochlorite method of sterilization and of storage of bottles and teats produced significantly better results. More of the mothers with satisfactory results had attended mothercraft classes. Twenty-two per cent. of babies in the sample were said to have suffered from diarrhoea, or vomiting, or both.

The standards of home sterilization of bottles and teats could be improved, and straightforward and effective health education is required, together with professional backing, so that mothers would put into practice what they had been taught.

During this century in Great Britain the infant mortality rate has steadily improved. The principal reason for this is the reduction in deaths from infectious diseases, including gastroenteritis; one of the consequences has been the adoption by doctors, nurses, and patients of a much more complacent attitude towards preventing enteritis in infants, greater reliance being placed on efficient therapy. Much time and effort, however, is still spent, particularly by health visitors, on one aspect of prevention-namely, advising mothers of the need to sterilize baby-feeding utensils adequately. Below we consider how effectively this advice is being carried out in the home.

In an earlier study (Gatherer and Wood, 1966) it was shown that the number of mothers who knew how to sterilize bottles and teats was far in excess of the number who were actually doing it correctly. The mothers who were interviewed all lived

\footnotetext{
*Director, Department of Community Medicine, Guy's Hospital Medical School, London S.E.1.

† Medical Officer of Health, Reading.
}

in the same town and were a rather selected group; nevertheless, the results aroused interest and it was decided to repeat the study in a number of different areas and to use a more random sample of mothers.

\section{Method}

Four areas in Great Britain were approached and the M.O.H.s agreed to take part: these were: Area A, a large industrial city in the north; Area $\mathrm{B}$, a medium-sized town in the north; Area $C$, a mixed industrial and rural county in the Midlands; and Area D, a rural county in the south.

In each of the four authorities an area was selected which contained a cross-section of socio-economic groups and which was geographically convenient for the participating public health laboratory. In each area sample lists of babies aged between 2 and 4 months were drawn up.

\section{Collection of Bottles and Teats}

The health visitors undertaking the survey called without warning on the mothers at a time which they estimated would be just before the morning feed. The bottle and teat to be collected had to be, in the mother's opinion, clean and ready to be filled with the feed. The bottles and teats were placed by the mother into sterile paper bags which were previously sealed and which were opened aseptically by the health visitors. The bag and contents were delivered to the laboratory and a sterile replacement bottle and teat were given to the mother.

A short structured questionary was completed by the health visitor. Usually this was done at the time of collection of the bottles and teats. Questions were put to the mothers concerning their knowledge of and attitudes to methods of sterilization in the home.

The possibility that the results for bottles taken from hypochlorite solution could be influenced by any residual 
solution was considered. It was technically difficult to ensure immediate neutralization of residual hypochlorite in every case, but in one area this was done by using a solution of sodium thiosulphate at the moment of collection for half the bottles in that sample, the intention being that there should be controls for the bottles from the other areas. All the bottles and teats were "neutralized" in the laboratory to which they were delivered within a few hours of collection. They were rinsed in $10 \mathrm{ml}$. of Ringer's solution with $0.5 \%$ thiosulphate, and 1-ml. samples of the rinse were subsequently cultured. Results were expressed as colony counts per $\mathrm{ml}$. (of rinse), and on the advice of one of the bacteriologists counts of up to $5 / \mathrm{ml}$. have been regarded as satisfactory, while those of six or more have been classed unsatisfactory. In addition the laboratory report indicated the presence or absence of $(a)$ presumptive coliform organisms and (b) Escherichia (faecal) coli.

\section{Results}

A total of 1,000 houses were selected in the areas of the four authorities, but in only 758 cases were the health visitors successful in obtaining bottles and teats and getting the questionary completed. The usual reason for failure was that the mother did not have the bottles or teats "ready for the feed." It was felt that this failure rate had to be accepted as the price of not warning the mothers about the survey.

Less than two-thirds of the bottles and iust over half of the teats produced results within the arbitrary "satisfactory" level of five or fewer colonies. Area B was significantly worse than the other areas, both for bottles and for teats $(P<0.001$ in each case). The results for this area in respect of the presence of coliforms and of $E$. coli were also significantly higher than in the other three areas (see Table I). Most mothers $(94 \%$ of those interviewed) claimed that they sterilized their baby's feeding-bottles and teats and there was very little regional variation in this respect.

TABLE I.-Bacteriological Results by Area

\begin{tabular}{|c|c|c|c|c|c|c|}
\hline & & Area A & Area B & Area C & Area D & Total \\
\hline \multicolumn{7}{|c|}{ Bottles } \\
\hline ) & & $|124(62 \%)|$ & $89(45 \%)$ & $|121(69 \%)|$ & $|141(78 \%)|$ & $475(63 \%)$ \\
\hline $\begin{array}{l}\text { Unsatustactory } \\
\text { (over } 5 \text { colonies) } \\
\text { Coliforms present } \\
\text { E. coli identified }\end{array}$ & $\begin{array}{l}. . \\
.\end{array}$ & $\begin{array}{c}77(38 \%) \\
24(12 \%) \\
8(4 \%)\end{array}$ & $\begin{array}{r}111(56 \%) \\
58(29 \%) \\
26(13 \%)\end{array}$ & $\begin{array}{r}54(31 \%) \\
12(7 \%) \\
4(2 \%)\end{array}$ & $\begin{array}{r}41(23 \%) \\
27(15 \%) \\
7(4 \%)\end{array}$ & $\begin{array}{r}283(37 \%) \\
121(16 \%) \\
45(6 \%)\end{array}$ \\
\hline $\begin{array}{l}\text { Satisfactory (0-5) } \\
\text { Unsatisfactory }\end{array}$ & & $\left|\begin{array}{r}105(52 \%) \\
96(48 \%)\end{array}\right|$ & $\begin{array}{c}\text { Teats } \\
32(16 \%) \\
168(84 \%)\end{array} \mid$ & $\left|\begin{array}{r}128(73 \%) \\
47(27 \%)\end{array}\right|$ & $\begin{array}{r}130(72 \%) \\
52(28 \%)\end{array}$ & $\begin{array}{l}395(52 \%) \\
363(48 \%)\end{array}$ \\
\hline Total & & 201 & 200 & 175 & 182 & 758 \\
\hline
\end{tabular}

Methods of sterilization differed; figures for both bottles and teats indicate this: 362 mothers $(48 \%)$ used the hypochlorite method alone, while $230(30 \%)$ relied solely on boiling; $11 \%$ used both methods together, and the remainder either used another method or did nothing. There were differences

$\ddagger$ Details of the method, etc., may be obtained from Dr. A. Gatherer. between areas in the pattern of sterilization; thus in Areas C and $D$, which were county areas and therefore more rural than the others, more mothers relied on hypochlorite alone (118 (67\%) and $104(57 \%)$ respectively), while the two urban areas had fewer mothers in this category $(81(40 \%)$ and 59 $(30 \%)$ respectively).

In all four areas and for both teats and bottles the results obtained from bottles sterilized by the hypochlorite method are more satisfactory than those sterilized by boiling (Table II). Overall, $78 \%$ of bottles and $70 \%$ of teats sterilized by hypochlorite had five or fewer colonies per ml. of rinse, contrasted with $46 \%$ of bottles and $34 \%$ of teats sterilized by boiling. In Area B 102 bottles were "neutralized" by thiosulphate immediately after collection and 98 were sent to the laboratory first. Forty bottles $(39 \%)$ of the group which were neutralized immediately and $49(50 \%)$ of the group which were not treated in this way were classed as satisfactory. Of the 59 bottles which were sterilized by hypochlorite only 28 were neutralized immediately and 31 were not; $14(50 \%)$ of the former and $19(61 \%)$ of the latter were found to be "satisfactory." There were 85 bottles from this same area which were sterilized by boiling only and 46 of these were subjected to the "neutralization" procedure by the health visitor immediately on collection, while 39 were sent straight to the laboratory; $14(30 \%)$ of the former and $16(41 \%)$ of the latter were found to be satisfactory. These differences do not reach the level of statistical significance, but they indicate that the addition of neutralizing agents reduces the chance of obtaining a satisfactory count even when the agent is added to bottles which have not been sterilized by hypochlorite.

Apart from distinguishing between the different methods of sterilization the study obtained information about other aspects of food preparation.

\section{Cleansing Procedures}

The importance of thorough cleansing of bottles and teats before sterilization is not always appreciated, and failure to do so may be one of the reasons for poor results. Detailed information on this point was therefore obtained, and Table III shows some of the different methods which mothers used to clean utensils.

Fewer mothers using the hypochlorite method used boiling/hot water for rinsing than mothers favouring the boiling method. But there was otherwise an interesting difference between the two groups of mothers, with more of the "hypochlorite" mothers using a more thorough cleansing routine than the others-more of them used bottle brushes and liquid detergent, more rubbed the teats with salt and turned them inside out.

\section{Storage between Feeds}

The previous study emphasized the advantages in the sterilization process of storing bottles and teats in hypochlorite solution between feeds. In this study a similar result

\begin{tabular}{|c|c|c|c|c|c|c|c|c|c|c|c|c|c|c|c|}
\hline \multirow[b]{2}{*}{ Method used: } & & & & & & \multicolumn{2}{|c|}{ Area $\mathrm{A}$} & \multicolumn{2}{|c|}{ Area B } & \multicolumn{2}{|c|}{ Area C } & \multicolumn{2}{|c|}{ Area D } & \multicolumn{2}{|c|}{ Total } \\
\hline & & & & & & $\mathbf{H}$ & B & $\mathbf{H}$ & B & H & B & H & B & H & B \\
\hline $\begin{array}{l}\text { Satisfactory .. } \\
\text { Unsatisfactory }\end{array}$ & $\because$. & $\because$ & $\because$ & $\because$ & $\because$. & $\begin{array}{l}62(77 \%) \\
19(23 \%)\end{array}$ & $\begin{array}{l}38(48 \%) \\
41(52 \%)\end{array}$ & $\begin{array}{c}B C \\
33(56 \%) \\
26(44 \%)\end{array}$ & $\begin{array}{l}\text { tzles } \\
30(35 \%) \\
55(65 \%)\end{array}$ & $\begin{array}{l}93(79 \%) \\
25(21 \%)\end{array}$ & $\begin{array}{l}16(50 \%) \\
16(50 \%)\end{array}$ & $\begin{array}{l}93(89 \%) \\
11(11 \%)\end{array}$ & $\begin{array}{l}23(64 \%) \\
13(36 \%)\end{array}$ & $\mid \begin{array}{r}281(78 \%) \\
81(22 \%)\end{array}$ & \begin{tabular}{|l}
$106(46 \%)$ \\
$124(54 \%)$
\end{tabular} \\
\hline Total & .. & .. & .. & .. & .. & 81 & 79 & 59 & 85 & 118 & 32 & 104 & 36 & 362 & 230 \\
\hline $\begin{array}{l}\text { Satisfactory .. } \\
\text { Unsatisfactory }\end{array}$ & $\therefore$ & $\because$ & $\because$ & $\therefore$ & .. & $\begin{array}{l}55(69 \%) \\
25(31 \%)\end{array}$ & $\begin{array}{l}31(40 \%) \\
47(60 \%)\end{array}$ & $\begin{array}{c}\mathrm{Te} \\
15 \text { (25\%) } \\
44(75 \%)\end{array}$ & $\begin{array}{l}75 \quad 6(7 \%) \\
79(93 \%)\end{array}$ & $\begin{array}{l}97(82 \%) \\
21(18 \%)\end{array}$ & $\begin{array}{l}19(59 \%) \\
13(41 \%)\end{array}$ & $\begin{array}{l}86(83 \%) \\
18(17 \%)\end{array}$ & $\begin{array}{l}21(62 \%) \\
13(38 \%)\end{array}$ & $\mid \begin{array}{l}253(70 \%) \\
108(30 \%)\end{array}$ & $\mid \begin{array}{r}77(34 \%) \\
152(66 \%)\end{array}$ \\
\hline Total & .. & .. & .. & .. & .. & 80 & 78 & 59 & 85 & 118 & 32 & 104 & 34 & 361 & 229 \\
\hline
\end{tabular}

N.B. 166 mothers who sterilized bottles by other methods (or who used both methods together) have been excluded from the bottle results. Similarly 168 mothers are excluded 
Table III.-Cleansing Procedure Used

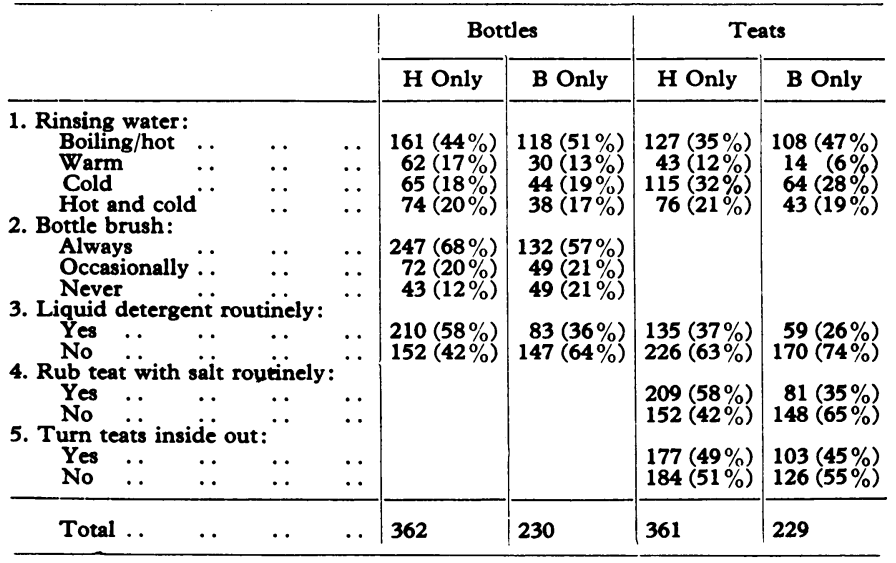

was obtained. Of the total sample, 421 mothers (56\%) stored bottles in hypochlorite solution, while $137(18 \%)$ stored them in boiled water, etc. ("wet") and 200 (26\%) in cupboards and similar places ("dry"). The bacteriological results were good for those stored in hypochlorite, producing satisfactory results for $327(78 \%)$ compared with only $64(47 \%)$ stored in boiled water and $84(42 \%)$ stored "dry."

The findings for teats showed the same trend $(72 \%$ hypochlorite, $33 \%$ wet, and $28 \%$ dry), and this pattern for both bottles and teats was the same in each of the four areas. but in Area B, where hypochlorite was relatively less popular, the trend was not so pronounced as in the other three areas.

\section{Mother's Knowledge and Attitudes}

Only $51(7 \%)$ mothers did not feel that sterilization of bottles and teats was necessary-18 thought that pouring boiling water over the bottle was sufficient, 19 thought it was no longer necessary owing to the age of the baby, 10 "could not be bothered," and only $4(0.5 \%$ of the total sample) said they did not know about it.

Just over a third of mothers interviewed (285) had attended mothercraft classes at one time. There was a wide variation between the areas, with $102(58 \%)$ and $87(48 \%)$ in the country areas (C and D respectively), $80(40 \%)$ in the city (A), and only $16(8 \%)$ in the area (B) saying they had attended classes.

Most mothers first heard about bottle and teat sterilization from "professional" sources: Hospital (174 or $24 \%$ ), antenatal classes $(151$ or $21 \%$ ), friend or relative (151 or $21 \%$ ), and magazine or baby book (97 or $14 \%$ ). It was interesting to find that $46 \%$ of the 475 mothers with satisfactory bottles and $51 \%$ of the 395 with satisfactory teats said they had attended mothercraft classes; these proportions are significantly higher than those with bacteriologically unsatisfactory utensils $(23 \%$ bottles and teats).

Mothers were asked if they thought there were any dangers to the child if bottles and teats were not sterilized and most $(88 \%)$ said there were. The main dangers were considered to be "gastroenteritis/tummy upsets" ( $40 \%)$, thrush/mouth infection $(24 \%)$, and diarrhoea $(17 \%)$. About one-third of mothers made vague reference to "germs/bacteria."

Of the 475 mothers with satisfactory bottles 442 (93\%) indicated by their answers that they knew about the dangers of inadequate sterilization; this contrasted with $226(80 \%)$ of 283 mothers with unsatisfactory bottles. These results were confirmed by considering the number of babies (165 $(22 \%)$ of the sample) who were said to have suffered from diarrhoea and/or vomiting: $92(19 \%)$ of the satisfactory group had had this complaint as opposed to $73(26 \%)$ of the unsatisfactory group (0.05>P $>0.01)$. It is perhaps worth recording in this connexion that $134(81 \%)$ of the 165 mothers of children who had had sickness/diarrhoea had consulted their general practitioners.

\section{General Data}

Standards of Home Hygiene and Baby Care.-Information on occupation of head of household was rather scanty in some cases and so the social class groupings are unreliable. Each home in the survey, however, was assessed by the health visitors; $354(47 \%)$ were rated "good" or "above average" so far as home hygiene was concerned. There were only slight variations in these levels between the areas. There were, however, differences between mothers with satisfactory results and those with unsatisfactory bottles in this respect. While 268 $(56 \%)$ mothers with satisfactory standards had "above average" standards of home hygiene, only $86(30 \%)$ of those with unsatisfactory results had the same assessment. A parallel assessment of "good" or "above average" standard of baby care showed the same trend.

Age Group and Parity Effects.-The variations in the results between different age groups of the mothers were not significant; unsatisfactory results were slightly more common in the mothers in the youngest age group (16-24 years), in which 136 out of $349(39 \%)$ were in this category, compared with 119 out of $340(35 \%)$ of the remainder, for whom ages were ascertained. There was also a difference in the results between mothers with only one child and those with more than onethose with a first baby had better bacteriological results (202 $(70 \%)$ out of 288 with satisfactory results) than those having subsequent babies (273 $(58 \%)$ out of 470 with satisfactory results).

\section{Discussion}

This study sought to assess behaviour and knowledge of sterilization methods in four areas of the country, representing a wide range of social and environmental characteristics. The limitations, however, have to be clearly recognized. For example, complete standardization of opinion among health visitors and even of the bacteriological work was hampered by the multiplicity of workers; furthermore, the areas were selected mainly because of their proximity to participating public health laboratories. For these reasons differences between areas should not be stressed unduly.

The findings confirm those of the pilot study (Gatherer and Wood, 1966), and there seems little doubt that the standards of home sterilization of infant feeding-bottles and teats could be greatly improved. If the bacteriologists' view that more than five colonies per $\mathrm{ml}$. of rinse is unsatisfactory is accepted, then it is sad that only $63 \%$ of bottles and $52 \%$ of teats were in the satisfactory class. The poor figures from the teats especially indicate an area where further teaching should be considered. It is very unlikely that utensils from the homes where they were deemed to be "not ready for feeding" would have had a higher proportion rated as satisfactory. It seems fair to assume, therefore, that the proportions of bottles and teats in all the homes in the sample which would be unsatisfactory when feeding began would be higher than that shown by the figures in this study.

The influence of social and educational factors on the results was obvious, and it did not take research like this to prove that the better mothers get better results regardless of method used. But there were one or two points from this part of the study which deserve further consideration. The slight increase in the unsatisfactory results from the youngest group of mothers may suggest that a greater effort should be made to educate girls (and boys) in secondary schools on this and other basic aspects of home hygiene.

The important role of the hospital in the health education of mothers came out clearly, for two-thirds of the mothers first heard of sterilization of bottles and teats at hospital or antenatal clinic. The shorter stay of mothers and the use of 
disposable equipment and machine dispensing are modern trends which may reduce the opportunities for teaching. Hospital maternity units will need to consider this point, and the domiciliary midwife (or health visitor) at a later stage will carry even more responsibility for ensuring that mothers have the information, that they understand it, and that they act accordingly.

The investigation shows that in the artificial feeding of babies the mothers who used the hypochlorite method of sterilization of bottles and teats produced significantly better results. This finding may have been due to the continuing action of traces of the agent during its transport to the laboratory, but evidence in support did not reach statistically significant proportions in the one area where this was tested. Mothers adopting this method, however, were more inclined to clean the utensils better beforehand, and they stored them in solution, thus avoiding subsequent contamination.

Undoubtedly, many factors are involved in achieving satisfactory results by either method-social class, educational level, mothercraft advice obtained, and so on. It may even be that (in the words of one of the doctors involved in the project) "a 'method of sterilization,' presumed to be based on chemistry, is followed more carefully and thoroughly than the use of a 'procedure' (boiling) which is regarded more as a domestic activity." Over one-fifth of babies had suffered from diarrhoea and vomiting that was usually serious enough for the mother to consult her doctor. This can be taken as evidence that gastroenteritis is not entirely a thing of the past, even though the consequences may be less serious than in former days.

The basic problem highlighted by this study is that so many mothers failed to carry out sterilization procedures effectively in spite of the fact that they had received "health education" in this field. Information of how to do it and why it should be done had been put across but the resultant behaviour did not seem to reach the necessary standard. This is a fundamental problem of health education-the communication of ideas is insufficient in itself and must be associated with a desire to change habits. There would seem to be a need for (a) straightforward yet effective health education materials, and (b) professional backing so that mothers adopt a routine which gives protection to their babies. Why are the results so bad when effective methods are readily available?

While it is not possible to indicate individually the many people who willingly co-operated in this study, we would like to express our gratitude and indebtedness to them. The study would obviously have been impossible without the joint effort of doctors, health visitors, and technicians in the local authority and public health laboratory services. of Health and the Public Health Laboratory Service, 25, 126.

\title{
Comparison of Effect of Salbutamol and Isoprenaline on Spirometry and Blood-gas Tensions in Bronchial Asthma
}

\author{
K. N. V. PALMER, * M.D., F.R.C.P. ; J. S. LEGGE, † M.B., CH.B. ; W. F. D. HAMILTON, $\ddagger$ M.B., CH.B. \\ M. L. DIAMENT, $\$ M.D.
}

\begin{abstract}
ummary: The effect of the aerosol inhalation of $200 \mu \mathrm{g}$. $N$ of salbutamol and $1,000 \mu \mathrm{g}$. of isoprenaline on spirometry and blood-gas tensions was compared in the same 11 asthmatic subjects. Both drugs significantly reduced airway obstruction, and the extent of the reduction did not differ for periods of up to 30 minutes. After isoprenaline tachycardia and a small significant fall in arterial oxygen tension occurred, whereas after salbutamol there was no change in pulse rate and the arterial oxygen tension did not fall.
\end{abstract}

\section{Introduction}

Salbutamol is a new type of sympathomimetic bronchodilator drug which is claimed to act selectively on $\beta 2$-adrenergic receptors in bronchial muscle without significant stimulation of $\beta 1$-receptors in the myocardium. In asthma it has been shown to produce bronchodilatation without increasing pulse rate, blood pressure (Choo-Kang et al., 1969; Kennedy and Simpson, 1969), or cardiac output (Kelman et al., 1969). Isoprenaline, on the other hand, is a powerful stimulator of $\beta$ receptors in both bronchial and cardiac muscle, so that in addition to relaxing smooth muscle in the bronchi it also increases cardiac output (Aviado and Schmidt, 1957; Kelman et al. 1969). Probably as a direct result of its action on the cardiovascular system, hypoxaemia may become worse after isoprenaline even though airway obstruction is diminished (Field,

\footnotetext{
* Reader in Medicine, University of Aberdeen.

+ Research Fellow, University of Aberdeen.

$¥$ Research Assistant, University of Aberdeen.

$\$$ Lecturer in Physiology, University of Aberdeen.
}

1967; Palmer and Diament, 1967). There is evidence that salbutamol in relieving airway obstruction does not lead to a fall in lowered arterial oxyen tension $\left(\mathrm{PaO}_{2}\right)$ (Palmer and Diament, 1969a, 1969b), and that its action lasts longer than that of isoprenaline (Choo-Kang et al., 1969). Because of the known variability of the response of asthmatic patients to bronchodilator drugs it is important to compare the response to salbutamol and isoprenaline in the same patient. We report here the effect of these drugs on spirometry and arterial blood-gas tensions in the same asthmatic patients.

\section{Patients and Methods}

Eleven asthmatic outpatients (seven men and four women) were investigated. The nature of the experiment was explained to them and all gave their consent. Their mean age w2s 46 ( \pm 12.7$)$ years, height $62.5( \pm 2.86)$ in. (159 ( \pm 7.26) cm.), and weight $151.3( \pm 19.4) \mathrm{lb}$. (68.6 ( \pm 8.8) kg.) All had long attacks of airway obstruction. Seven had positive scratch tests to various allergens and nine had sputum and/or blood easinophilia. They attended the laboratory on three separate occasions when arterial bood-gas tensions, dynamic lung volumes, pulse, and blood pressure were measured before and at intervals of up to $\mathbf{3 0}$ minutes after either the aerosol-inhalation of $1,000 \mu \mathrm{g}$. of isoprenaline or $200 \mu \mathrm{g}$. of salbutamol. Blood samples were obtained in a heparin-lubricated syringe from the brachial or radial artery when the patient was breathing air, and $\mathrm{PaO}_{2}, \mathrm{PaCO}_{2}$, and $p \mathrm{H}$ were measured in duplicate with electrodes manufactured by Radiometer, Copenhagen. The standard deviation of a single measurement in our hands was $1.7 \mathrm{~mm} . \mathrm{Hg}$ for the oxygen electrode and 